\title{
Variation in nitrogen use strategies and photosynthetic pathways among vascular epiphytes in the Brazilian Central Amazon ${ }^{1}$
}

\author{
SÍLVIA FERNANDA MARDEGAN ${ }^{2,5}$, GABRIELA BIELEFELD NARDOTO², NIRO HIGUCHI ${ }^{3}$, \\ FERNANDA REINERT ${ }^{4}$ and LUIZ ANTONIO MARTINELLI ${ }^{2}$
}

(received: August 18, 2009; accepted: December 2, 2010)

\begin{abstract}
Variation in nitrogen use strategies and photosynthetic pathways among vascular epiphytes in the Brazilian Central Amazon). The variation in nitrogen use strategies and photosynthetic pathways among vascular epiphyte families was addressed in a white-sand vegetation in the Brazilian Central Amazon. Foliar nitrogen and carbon concentrations and their isotopic composition $\left(\delta^{15} \mathrm{~N}\right.$ and $\delta^{13} \mathrm{C}$, respectively) were measured in epiphytes (Araceae, Bromeliaceae and Orchidaceae) and their host trees. The host tree Aldina heterophylla had higher foliar N concentration and lower C:N ratio $(2.1 \pm 0.06 \%$ and $23.6 \pm 0.8)$ than its dwellers. Tree foliar $\delta^{15} \mathrm{~N}$ differed only from that of the orchids. Comparing the epiphyte families, the aroids had the highest foliar $\mathrm{N}$ concentration and lowest C:N ratios $\left(1.4 \pm 0.1 \%\right.$ and $34.9 \pm 4.2$, respectively). The orchids had more negative foliar $\delta^{15} \mathrm{~N}$ values $(-3.5 \pm 0.2 \%)$ than the aroids $(-1.9 \pm 0.7 \%)$ and the bromeliads $(-1.1 \pm 0.6 \%)$. Within each family, aroid and orchid taxa differed in relation to foliar $\mathrm{N}$ concentrations and $\mathrm{C}: \mathrm{N}$ ratios, whereas no internal variation was detected within bromeliads. The differences in foliar $\delta^{15} \mathrm{~N}$ observed herein seem to be related to the differential reliance on the available $\mathrm{N}$ sources for epiphytes, as well as to the microhabitat quality within the canopy. In relation to epiphyte foliar $\delta^{13} \mathrm{C}$, the majority of epiphytes use the waterconserving CAM-pathway $\left(\delta^{13} \mathrm{C}\right.$ values around $-17 \%$ ), commonly associated with plants that live under limited and intermittent water supply. Only the aroids and one orchid taxon indicated the use of $\mathrm{C}_{3}$-pathway $\left(\delta^{13} \mathrm{C}\right.$ values around $-30 \%$ ).
\end{abstract}

Key words $-\delta^{13} \mathrm{C}, \delta^{15} \mathrm{~N}$, stable isotopes, white-sand vegetation

RESUMO - (Variação nas estratégias de uso do nitrogênio e nas vias fotossintéticas entre epífitas vasculares na região central da Amazônia, Brasil). A variação nas estratégias de uso do nitrogênio e das vias fotossintéticas de famílias de epífitas vasculares foi investigada em uma vegetação de areia branca na Amazônia Central. Foram medidas as concentrações e composições isotópicas de nitrogênio e carbono $\left(\delta^{15} \mathrm{~N}\right.$ e $\delta^{13} \mathrm{C}$, respectivamente) de folhas de epífitas (Araceae, Bromeliaceae e Orchidaceae), assim como de suas árvores hospedeiras. As folhas da árvore hospedeira Aldine heterophylla tiveram a maior concentração de nitrogênio foliar e menor razão C:N $(2,1 \pm 0,06 \%$ e $23,6 \pm 0,8)$ que de suas hóspedes. $\mathrm{O}$ valor de $\delta^{15} \mathrm{~N}$ foliar da árvore somente diferiu do valor das orquídeas. Ao comparar as famílias de epífitas, a maior concentração de nitrogênio foliar e menor razão C:N foi observada nas aráceas $\left(1,4 \pm 0,1 \%\right.$ e $34,9 \pm 4,2$, respectivamente). As orquídeas tiveram valores mais negativos de $\delta^{15} \mathrm{~N}$ foliar $(-3,5 \pm 0,2 \%)$ que aráceas $(-1,9 \pm 0,7 \%)$ e bromélias $(-1,1 \pm 0,6 \%$ ). Ao comparar os táxons de cada família, observou-se que tanto os táxons de aráceas como os de orquídeas diferiram em relação ao nitrogênio foliar e razão C:N, enquanto que não foi detectada variação entre os táxons de bromélias. As diferenças nos valores de $\delta^{15} \mathrm{~N}$ foliar aqui observadas podem ser relacionadas à variação na dependência das fontes de nitrogênio disponíveis para as epífitas, assim como na variação da qualidade do microhabitat no dossel. Em relação aos valores de $\delta^{13} \mathrm{C}$ foliar das epífitas analisadas, verificou-se que a maioria usa a via fotossintética CAM (valores em torno de $-17 \%$ ), comumente associada com plantas que vivem em condições de suprimento de água limitado ou intermitente. Apenas as aráceas e um táxon de orquídea mostraram usar a via $\mathrm{C}_{3}$ (valores em torno de $-30 \%$ ).

Palavras-chave $-\delta^{13} \mathrm{C}, \delta^{15} \mathrm{~N}$, isótopos estáveis, vegetações de areia branca

\section{Introduction}

A portion of the Amazon Basin not seasonally flooded, also known as terra-firme, is mainly covered

1. Part of the first author's MSc Dissertation. Programa de PósGraduação em Ecologia, Instituto Nacional de Pesquisas da Amazônia, Manaus, AM, Brazil.

2. Universidade de São Paulo, Centro de Energia Nuclear na Agricultura, Avenida Centenário, 303, 13416-000 Piracicaba, SP, Brazil.

3. Instituto Nacional de Pesquisas da Amazônia, Avenida André Araújo, 2936, 69060-001 Manaus, AM, Brazil.

4. Universidade Federal do Rio de Janeiro, CCS, Departamento de Botânica, IB, 21941-970 Rio de Janeiro, RJ, Brazil.

5._Corresponding author: smardegan@usp.br by lowland tropical forest (Braga 1979, Pires \& Prance 1985). Although the Amazon forest and white-sand soils are not often associated, terra-firme forest is scattered with a substantial proportion of evergreen sclerophyllous vegetation, characterized by elevated endemism and low diversity (Braga 1979, Anderson 1981). This vegetation is known as "heath forest" and comprises stunted (campina) and taller (campinarana) formations (Proctor 1999, Luizão et al. 2007a, b). Compared with the terra-firme Amazonian forest, its canopy is less dense allowing more light to reach the lower understory. Epiphytes are abundant on its tree branches as well as on the ground (Takeuchi 1960, Guillamet 1987). 
Epiphytes are a conspicuous and characteristic life form in tropical forests (Richards 1996, Benavides et al. 2005), accounting for up to 35 percent of the vascular flora in some wet neotropical forests (Gentry \& Dodson 1987). In some cloud forests, their biomass rivals that of tree foliage (Nadkarni 1984, Nadkarni et al. 2000, Stewart et al. 2002), while in some montane rainforests, their foliage may equal 50 percent of tree leaf biomass (Edwards \& Grubb 1977, Nadkarni 1984, Ingram \& Nadkarni 1993). As they produce a considerable amount of suspended biomass and retain water and debris (Nadkarni 1986), epiphytes and associated dead organic matter constitute a considerable portion of the aboveground biomass and nutrient pools in these systems (Nadkarni 1984), playing an important role in forest primary production and nutrient cycling (Nadkarni 1986, Zotz \& Winter 1994).

The epiphytic habit implies some physiological constraints as the demand for water and nutrients is often not buffered by layers of soil as the plants are not rooted in ground soil (Nadkarni 1984, Nadkarni \& Matelson 1991, Hietz et al. 2002).

Epiphytes may only access $\mathrm{N}$ sources derived from the atmosphere (via wet and/or dry deposition or $\mathrm{N}_{2}$ fixation), canopy (organic forms derived from leaching or decomposition of trapped canopy litter, and also from inputs by animals) and epiphyte-microorganisms symbiosis (Stewart et al. 1995, Hietz et al. 2002, Inselsbacher et al. 2007). Furthermore, epiphytes are exposed to a higher insolation condition (Yoda 1974), greater extremes of temperature and relative humidity than forest understory vegetation (Ingram \& Nadkarni 1993).

The variety of morphological and physiological strategies allowed plants to successfully inhabit more exposed sites and completely evolve independently of ground soil (Benzing 1990). Epiphytes have slower growth rates, accessory structures (e.g. trichomes and velamen), as well as association with insects and microorganisms (Nadkarni 1984, Stewart et al. 1995, Kauff et al. 2000, Hietz et al. 2002, Rains et al. 2003, Tsavkelova et al. 2003, Shefferson et al. 2005).

The epiphytic habitat is generally the driest niche within tropical forests and many species use the photosynthetic water-conserving CAM-pathway, including epiphytes from Bromeliaceae, Cactaceae and Orchidaceae (Medina et al. 1977, 1989, Fontoura \& Reinert 2009). Moreover, morphological adaptations (water-storing phytotelmata, succulence, xeromorphic leaves, poikilohydry, deciduousness, and general reduction of the shoot) also allow many $\mathrm{C}_{3}$-species to live under these extreme conditions (Benzing 1990, Hietz et al. 1999).

The natural abundance of stable isotopes has been widely applied as a powerful tool in ecosystem and plant ecology research. While the natural abundance of ${ }^{15} \mathrm{~N}$ is a useful indicator of the sources and pathways of $\mathrm{N}$ (Högberg 1997), the $\delta^{13} \mathrm{C}$ values of leaves is widely used to identify the photosynthetic pathway and to estimate plant water-use efficiency (WUE) (Dawson et al. 2002, Holtum \& Winter 2005). Previous studies have pointed out differences in foliar $\delta^{15} \mathrm{~N}$ values of epiphytes and their host trees, where trees have more ${ }^{15} \mathrm{~N}$-enriched values than their dwellers due to differences in life style and use of differentiated $\mathrm{N}$ sources (Stewart et al. 1995). Stewart et al. (1995) also compared within epiphytes and were able to group them according to ${ }^{15} \mathrm{~N}$ depletion and $\mathrm{N}$ content, attributing these results to the differential use of $\mathrm{N}$ sources (wet and dry atmospheric deposition, debris and $\mathrm{N}_{2}$ fixation).

Differences in foliar $\delta^{15} \mathrm{~N}$ and $\delta^{13} \mathrm{C}$ of epiphytes may also be related to epiphytic group and environmental conditions. When comparing taxonomic and ecological groups of epiphytes along an altitudinal gradient, Hietz et al. (1999) pointed out that variation in epiphytic life form, physiology, as well as position of individuals within the canopy is capable of affecting $\mathrm{N}$ nutrition and foliar $\delta^{15} \mathrm{~N}$ values. A survey of $\delta^{15} \mathrm{~N}$ and $\delta^{13} \mathrm{C}$ signatures of $\mathrm{N}$ sources and epiphyte leaves sampled from different canopy strata provided evidence for a $\delta^{15} \mathrm{~N}$-gradient which varied with height: more positive values in the lower canopy zones to more negative values in the upper canopy zones (Wania et al. 2002). This variation was not only attributed to differences in $\mathrm{N}$-source use by epiphytes of different strata, but also to differences in isotope discrimination during $\mathrm{N}$ acquisition and internal variation. An inverse trend was observed for foliar $\delta^{13} \mathrm{C}$ values, as ${ }^{13} \mathrm{C}$ abundance increased from lower to upper zones. This reduction in ${ }^{13} \mathrm{C}$ discrimination was related to the lower water availability and/or light incidence experienced by epiphytes of higher strata.

In this paper, the foliar content of $\mathrm{N}$ and the relative abundances of foliar ${ }^{13} \mathrm{C}$ and ${ }^{15} \mathrm{~N}\left(\delta^{13} \mathrm{C}\right.$ and $\left.\delta^{15} \mathrm{~N}\right)$ of different taxonomic groups of vascular epiphytes (Araceae, Bromeliaceae and Orchidaceae) of a whitesand vegetation in Central Brazilian Amazon were measured in order to test whether epiphytes from different families had distinct strategies related to $\mathrm{N}$ use and photosynthetic pathways. Variations within families, as well as differences in the nutritional status between epiphytes and host tree species were also searched. 


\section{Material and methods}

Study site - The study was carried out at the Biological Reserve of Campina, administered by the Instituto Nacional de Pesquisas da Amazônia - Inpa. The reserve is situated $60 \mathrm{~km}$ north of the city of Manaus, AM, Brazil $\left(02^{\circ} 35^{\prime} \mathrm{S}\right.$, $60^{\circ} 02^{\prime} \mathrm{W}$ ), and covers an area of 900 ha. Climate in this region is tropical, with mean annual temperature of $26^{\circ} \mathrm{C}$ and air humidity ranging from $85-88 \%$. The annual precipitation in the region averages $2200-2400 \mathrm{~mm}$, with 2-3 months with less than $100 \mathrm{~mm}$ of rainfall (Sombroek 2001).

The Reserve is formed by campina (dense sclerophyllous shrub, 4-10 m high, generally forming a sparse cover over bare sand), campinarana (dense sclerophyllous forest, with trees 10-20 m high) and dense terra-firme forest (lowland tropical forest). The campina is usually surrounded by campinarana vegetation, and may show a gradual succession to the campinarana, the climax in white-sands (Braga 1979, Pires \& Prance 1985, Luizão et al. 2007a).

Campina and campinarana vegetations grow in this area on highly weathered sandy soils, composed primarily of quartz (Hydromorphic Spodosols) (table 1). White-sand soils are very similar to spodosols of temperate zones (Proctor 1999, Horbe et al. 2004), and are characterized by fast drainage, high acidity, and accumulation of a layer of mor humus of varying thickness over soil surface under woody vegetation patches (Anderson 1981, Horbe et al. 2004, Luizão et al. 2007a). The topography of the area is essentially flat with a mean altitude of $44 \mathrm{~m}$ above sea level (Luizão et al. 2007b).

Plant sampling - Plant material was sampled during the rainy season (April 2006). Four $200 \mathrm{~m}$ long to $10 \mathrm{~m}$ wide transects were established, ranging from open campina to campinarana vegetation.

In each transect, we sampled individuals of the seven most frequent tree species occurring in both campina and campinarana vegetations: Aldina heterophylla Spruce ex Benth. (Leguminosae; sub-family Papilionoidae),

Table 1. Number of host trees and respective epiphytes sampled in an area of white-sand vegetation in the Central Brazilian Amazon.

\begin{tabular}{lrccc}
\hline \multirow{2}{*}{ Tree species } & $n$ & \multicolumn{3}{c}{ Epiphytes sampled } \\
\cline { 3 - 5 } & & Aroids & Bromeliads & Orchids \\
\hline Aldina heterophylla & 25 & 13 & 7 & 20 \\
Clusia nemorosa & 9 & - & 1 & 8 \\
Matayba opaca & 3 & - & 1 & 2 \\
Miconia argyrophylla & 3 & - & 2 & 1 \\
Ouratea spruceana & 3 & - & 1 & 3 \\
Pagamea duckei & 5 & - & 1 & 5 \\
Protium heptaphyllum & 1 & - & - & 1 \\
\hline Total & 49 & 13 & 13 & 40 \\
\hline
\end{tabular}

Clusia nemorosa G. Mey (Clusiaceae), Matayba opaca Radlk. (Sapindaceae), Ouratea spruceana (Mart.) Engl. (Ochnaceae), Pagamea duckei Standley (Rubiaceae), Pradosia schomgburkiana (A. DC.) Cronq. subsp. schomgburkiana (Sapotaceae), and Protium heptaphyllum March. (Burseraceae), summing up 52 trees sampled (table 1). The full description of these trees and their nutrient status can be found in Mardegan et al. (2009). Only sampled trees where epiphytes were present were sampled.

From the branches of each sampled tree, the epiphytes from Araceae, Bromeliaceae and Orchidaceae families were sampled, summing up a total of 66 individuals (table 1). Although no height measurements of the trunk were made, epiphytes occurred in diverse canopy strata; some of them were sampled close to the ground, while other species could only be sampled after climbing the host tree.

Epiphytic taxa were indentified to the genus level, as no fertile material was found. Two aroids - Anthurium sp. and Stenospermation sp., three bromeliads - Aechmea sp., Guzmania sp. and Streptocalyx sp., and four orchids - Encyclia sp., Octomeria sp., Maxillaria sp. 1 and sp. 2 were identified.

For determining $\mathrm{N}$ and $\mathrm{C}$ concentration and their isotope ratios, four to five leaves of each epiphyte and around 10 leaves from their host tree were sampled. All samples were healthy fully expanded leaves.

Data analyses - Tree and vascular epiphyte leaf samples (100$200 \mathrm{~g}$ ) were oven-dried at $65^{\circ} \mathrm{C}$ until a constant weight and ground to a fine powder. Sub samples of 1-2 mg of organic ground material were sealed in tin capsules and combusted in a Carlo Erba elemental analyzer (Milan, Italy) to determine N and $\mathrm{C}$ concentrations. The gas generated from the combustion was purified in a gas chromatography column and passed directly to the inlet of a gas isotope ratio mass spectrometer (IRMS Delta Plus; Finnigan Mat, San Jose, California, USA). Internal standard (atropine) was included in each run. From these analyses, both the $\mathrm{N}$ and $\mathrm{C}$ isotope ratios $\left(\delta^{15} \mathrm{~N}\right.$ and $\delta^{13} \mathrm{C}$, respectively) and elemental concentrations $(\% \mathrm{~N}$ and $\% \mathrm{C}$ ) were obtained.

Stable isotope ratios are expressed in a parts-perthousand basis (\%) in "delta" notation: $\delta^{15} \mathrm{~N}$ or $\delta^{13} \mathrm{C}=$ $\left(\mathrm{R}_{\text {sample }} / \mathrm{R}_{\text {standart }}-1\right) \times 1000$; where $\mathrm{R}_{\text {sample }}$ and $\mathrm{R}_{\text {standard }}$ are the ratios of heavy isotope to light isotope of the samples and the respective standard. The international standards for $\mathrm{N}$ and $\mathrm{C}$ were the atmospheric air and Pee Dee Belemnite limestone, respectively.

Statistical analysis - First the epiphytes of the three families in relation to foliar $\mathrm{C}$ and $\mathrm{N}$ contents, $\mathrm{C}: \mathrm{N}$ ratios, and their $\mathrm{N}$ and $\mathrm{C}$ isotopic composition $\left(\delta^{13} \mathrm{C}\right.$ and $\left.\delta^{15} \mathrm{~N}\right)$ were compared. Taxa of each epiphyte family were also compared in order to determine variations within each family sampled. We also compared individuals of Aldina heterophylla, the tree species with the highest number of individuals, from which the majority of epiphytes were sampled (including the aroids, which were absent from other tree canopies), and their 
dwellers. Correlations were made between foliar $\mathrm{C}$ and $\mathrm{N}$ concentration and the isotopic signatures of ${ }^{13} \mathrm{C}$ and ${ }^{15} \mathrm{~N}$, as well as between $C: N$ ratios.

Data distribution was tested using the KolmogorovSmirnov one-sample test. Because some data did not follow normal distribution, the analyses were performed using nonparametric tests. Differences among each epiphyte family were tested using a Kruskal-Wallis test to determine statistically significant differences among the three groups compared. This test was also used to determine significant differences among the taxa of the families Bromeliaceae and Orchidaceae. As Araceae had only two taxa sampled, the Mann-Whitney U test was used to determine statistical differences.

All statistical analyses were performed using the software STATISTICA, version 6.1 for Windows (StatSoft Inc. 2004). A probability level of 0.05 was used as a critical level of significance in all tests.

\section{Results}

Comparisons among vascular epiphyte families Araceae species had the highest foliar $\mathrm{N}$ concentration and the lowest $\mathrm{C}: \mathrm{N}$ ratio $(P<0.05)$, while those from Bromeliaceae and Orchidaceae had similar average foliar
$\mathrm{N}$ concentration and $\mathrm{C}: \mathrm{N}$ ratio (table 2). The orchids had the most depleted foliar $\delta^{15} \mathrm{~N}$ values compared to the aroids and the bromeliads $(P<0.05)$. The aroids had more negative foliar $\delta^{13} \mathrm{C}$ values than bromeliads and orchids, $(P<0.05)$, while the latter had similar foliar $\delta^{13} \mathrm{C}$ values (table 2$)$.

Comparisons within epiphyte families - Comparisons within each epiphyte family revealed that within the aroids, the two taxa sampled (Anthurium sp. and Stenospermation sp.) significantly differed in relation to foliar $\mathrm{N}$ concentration and $\mathrm{C}: \mathrm{N}$ ratio $(P<0.05)$. Anthurium sp. had higher $\mathrm{N}$ concentration and lower C:N ratio than Stenospermation sp. $(P<0.05)$. Foliar $\delta^{15} \mathrm{~N}$ values were highly variable, ranging from -6.7 to $+3.8 \%$, while average foliar $\delta^{13} \mathrm{C}$ values were around $-30 \%$ (figure $1 \mathrm{~A}$, table 3 ).

No variation within the three bromeliad species (Aechmea sp., Guzmania sp., and Streptocalyx sp.) was detected in relation to $\mathrm{N}$ and $\mathrm{C}$ concentrations and their isotopic composition. Only Streptocalyx sp. had a more ${ }^{15} \mathrm{~N}$-enriched signature than the other two taxa (table 2). Foliar $\delta^{13} \mathrm{C}$ values did not vary significantly, and a

Table 2. Mean values ( $\pm \mathrm{SE}$ ) for foliar $\mathrm{N}$ and $\mathrm{C}$ concentration, $\mathrm{C}: \mathrm{N}$ ratio, and $\delta^{15} \mathrm{~N}$ and $\delta^{13} \mathrm{C}$ of epiphytes sampled in an area of white-sand vegetation in the Central Brazilian Amazon $(n=66)$.

\begin{tabular}{lcccc}
\hline $\begin{array}{l}\text { Epiphyte } \\
\text { Family }\end{array}$ & $\begin{array}{c}\mathrm{N} \\
(\%)\end{array}$ & $\mathrm{C}: \mathrm{N}$ & $\begin{array}{c}\delta^{15} \mathrm{~N} \\
(\%)\end{array}$ & $\begin{array}{c}\delta^{13} \mathrm{C} \\
(\%)\end{array}$ \\
\hline Araceae & $1.4 \pm 0.1^{\mathrm{a}}$ & $34.9 \pm 4.2^{\mathrm{a}}$ & $-1.9 \pm 0.7^{\mathrm{a}}$ & $-30.9 \pm 1.0^{\mathrm{a}}$ \\
Bromeliaceae & $0.9 \pm 0.1^{\mathrm{b}}$ & $55.6 \pm 4.9^{\mathrm{b}}$ & $-1.1 \pm 0.6^{\mathrm{a}}$ & $-17.3 \pm 0.2^{\mathrm{b}}$ \\
Orchidaceae & $0.8 \pm 0.01^{\mathrm{b}}$ & $56.3 \pm 1.7^{\mathrm{b}}$ & $-3.5 \pm 0.2^{\mathrm{b}}$ & $-21.9 \pm 1.0^{\mathrm{b}}$ \\
\hline
\end{tabular}

Different letters indicate significant statistical differences among epiphyte families $(P<0.05)$.

Table 3. Mean values ( \pm SE) for foliar $\mathrm{N}$ and $\mathrm{C}$ concentration, $\mathrm{C}: \mathrm{N}$ ratio, and $\delta^{15} \mathrm{~N}$ and $\delta^{13} \mathrm{C}$ of the taxa of each epiphyte family sampled in an area of white-sand vegetation in the Central Brazilian Amazon $(n=66)$.

\begin{tabular}{llccccc}
\hline Family & Taxa & $n$ & $\begin{array}{c}\mathrm{N} \\
(\%)\end{array}$ & $\mathrm{C}: \mathrm{N}$ & $\begin{array}{c}\delta^{15} \mathrm{~N} \\
(\%)\end{array}$ & $\begin{array}{c}\delta^{13} \mathrm{C} \\
(\%)\end{array}$ \\
\hline Araceae & Anthurium sp. & 7 & $1.6 \pm 0.1^{\mathrm{a}}$ & $26.9 \pm 1.5^{\mathrm{a}}$ & $-1.4 \pm 1.1^{\mathrm{a}}$ & $-31.7 \pm 0.3^{\mathrm{a}}$ \\
& Stenospermation sp. & 6 & $1.1 \pm 0.1^{\mathrm{b}}$ & $44.3 \pm 7.5^{\mathrm{b}}$ & $-2.4 \pm 1.0^{\mathrm{a}}$ & $-30.1 \pm 2.2^{\mathrm{a}}$ \\
Bromeliaceae & Aechmea sp. & 3 & $0.7 \pm 0.08^{\mathrm{a}}$ & $57.8 \pm 6.5^{\mathrm{a}}$ & $-2.1 \pm 0.9^{\mathrm{a}}$ & $-17.4 \pm 0.5^{\mathrm{a}}$ \\
& Guzmania sp. & 4 & $1.0 \pm 0.2^{\mathrm{a}}$ & $50.3 \pm 9.2^{\mathrm{a}}$ & $-2.0 \pm 0.8^{\mathrm{a}}$ & $-17.5 \pm 0.2^{\mathrm{a}}$ \\
& Streptocalyx sp. & 6 & $0.8 \pm 0.1^{\mathrm{a}}$ & $57.2 \pm 8.9^{\mathrm{a}}$ & $-0.02 \pm 1.0^{\mathrm{a}}$ & $-17.2 \pm 0.4^{\mathrm{a}}$ \\
Orchidaceae & Encyclia sp. & 12 & $1.0 \pm 0.03^{\mathrm{a}}$ & $47.9 \pm 1.6^{\mathrm{a}}$ & $-3.9 \pm 0.3^{\mathrm{a}}$ & $-32.2 \pm 0.2^{\mathrm{a}}$ \\
& Maxillaria sp. 1 & 12 & $0.7 \pm 0.02^{\mathrm{b}}$ & $66.3 \pm 3.2^{\mathrm{a}}$ & $-3.5 \pm 0.4^{\mathrm{a}}$ & $-17.4 \pm 0.1^{\mathrm{b}}$ \\
& Maxillaria sp. 2 & 12 & $0.9 \pm 0.02^{\mathrm{ab}}$ & $53.1 \pm 1.8^{\mathrm{ab}}$ & $-2.8 \pm 0.3^{\mathrm{a}}$ & $-17.8 \pm 0.2^{\mathrm{b}}$ \\
& Octomeria $\mathrm{sp}$. & 4 & $0.7 \pm 0.07^{\mathrm{b}}$ & $60.7 \pm 7.3^{\mathrm{ab}}$ & $-4.2 \pm 0.7^{\mathrm{a}}$ & $-17.3 \pm 0.1^{\mathrm{b}}$ \\
\hline
\end{tabular}

Different letters indicate significant statistical differences among species within each epiphyte family $(P<0.05)$. 
mean value of $-17.3 \pm 0.2 \%$ was observed (figure $1 \mathrm{~B}$, table 3).

Within the orchids, Encyclia sp. and Maxillaria sp.2 had similar foliar N concentration, as well as Maxillaria sp. 1 and Octomeria sp. $(P<0.05)$. The foliar $\mathrm{C}: \mathrm{N}$ ratio of the four taxa was highly variable. The foliar $\delta^{15} \mathrm{~N}$ values were negative and highly variable for the four species, with mean values ranging from -6.2 to -1.1\%o. Encyclia sp. had significantly more depleted foliar $\delta^{13} \mathrm{C}$ signature values compared to the other three taxa $(P<0.05)$ (figure 1C, table 3).

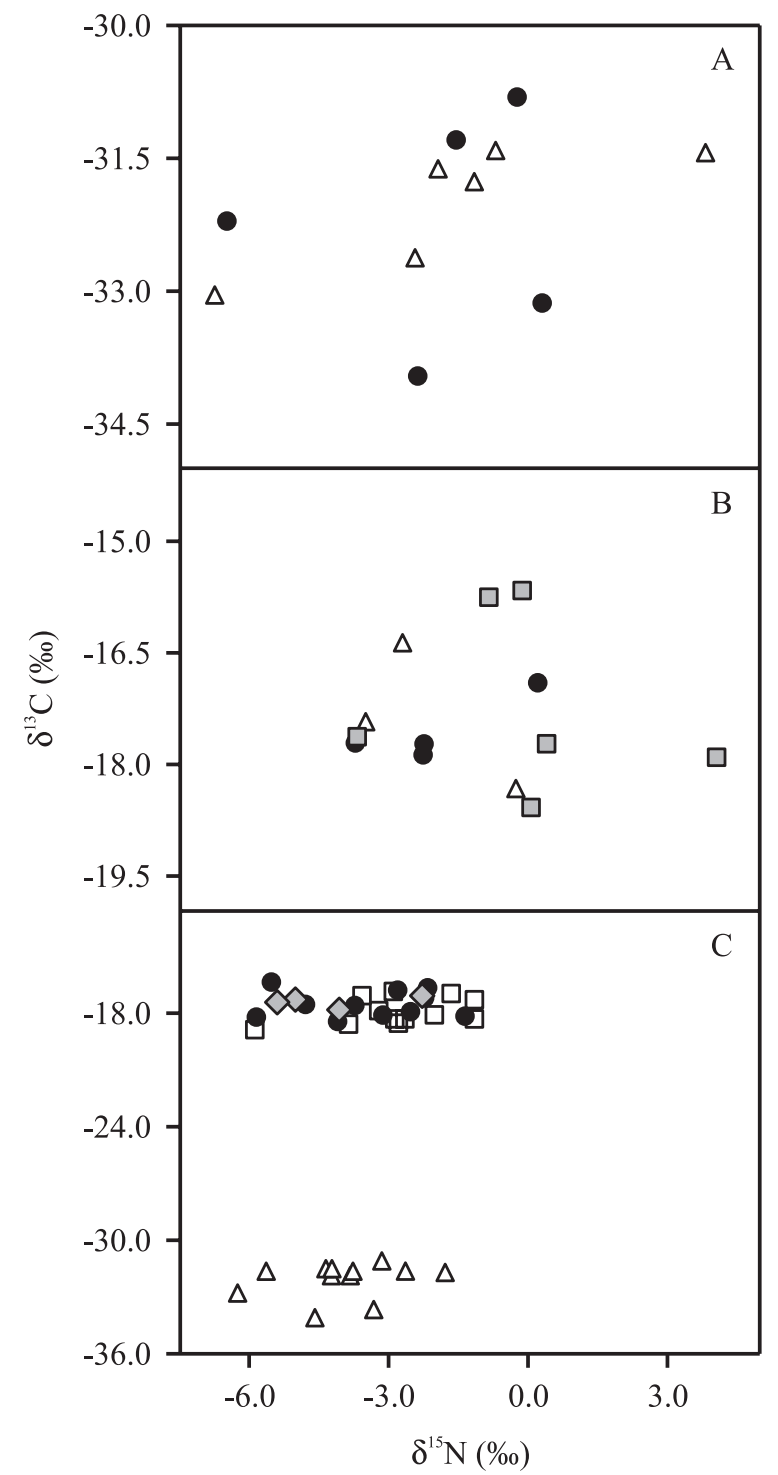

Figure 1. Foliar $\delta^{15} \mathrm{~N}$ and $\delta^{13} \mathrm{C}$ signatures of the taxa of the families Araceae (A)-Anthurium sp. $(\Delta)$ and Stenospermation sp. (•); Bromeliaceae (B) - Aechmea sp. ( $\triangle$ ), Guzmania sp. (๑) and Streptocalyx sp. ( $\square$ ); and Orchidaceae (C) - Encyclia sp. $(\triangle)$, Maxillaria sp.1 (•), Maxillaria sp.2 $(\square)$ and Octomeria sp. $(\diamond)$ sampled in an area of white-sand vegetation in the Central Brazilian Amazon.
Comparisons between host trees and epiphytes - The tree $A$. heterophylla had a higher foliar $\mathrm{N}$ concentration $(P<0.05)$ than the aroids, bromeliads, and orchids (table 4). Consequently, the host tree had a significantly lower $\mathrm{C}$ : N ratio $(P<0.05)$ than its dwellers (table 4$)$. $A$. heterophylla, had similar foliar $\delta^{15} \mathrm{~N}$ values to the aroid and the bromeliad dwellers, whereas the orchid dwellers had significantly more depleted signatures $(P<0.05)$ than their host (figure 2, table 4$)$. Regarding foliar $\delta^{13} \mathrm{C}$ values, the tree and its aroid dwellers had similar signatures, while the bromeliad and the orchid dwellers had less depleted values $(P<0.05)$ than their hosts (figure 2, table 4).

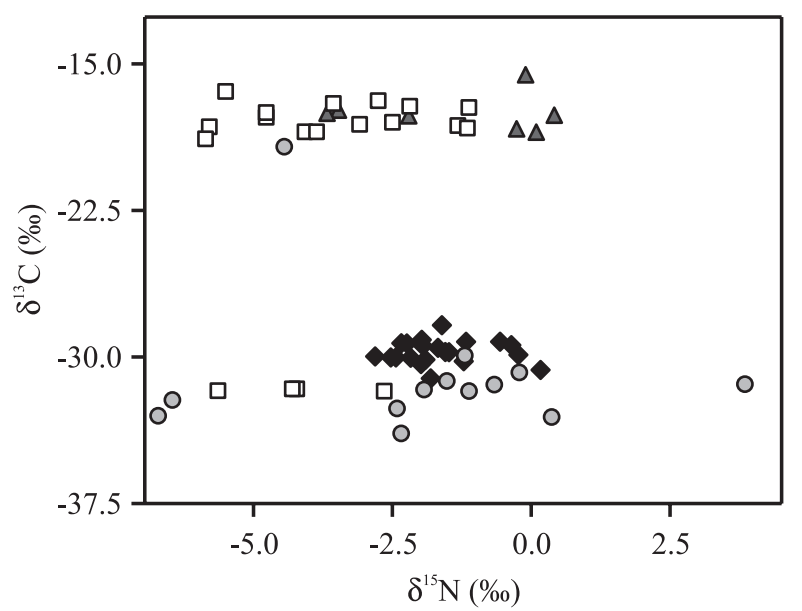

Figure 2. Foliar $\mathrm{N}$ and $\mathrm{C}$ isotopic signatures $\left(\delta^{15} \mathrm{~N}\right.$ and $\left.\delta^{13} \mathrm{C}\right)$ of $A$. heterophylla trees $(\bullet)$ and their dwellers - aroids $(\bigcirc)$, bromeliads $(\Delta)$ and orchids $(\square)$ sampled in an area of white-sand vegetation in the Central Brazilian Amazon.

\section{Discussion}

Potential sources of $\mathrm{N}$ to epiphytes using stable $\mathrm{N}$ isotopic composition - The divergence on foliar $\delta^{15} \mathrm{~N}$ values of epiphytes and their host trees is typically related to variation in life forms and $\mathrm{N}$ sources available for these plant groups. While forest trees are rooted in the soil, deriving the majority of nutrients from it, epiphytes derive at least a portion of their nutrients form atmospheric sources (atmospheric wet and dry deposition or biological $\mathrm{N}$ fixation), which are known to be more ${ }^{15} \mathrm{~N}$-depleted than soil (Nadkarni \& Matelson 1992, Stewart et al. 1995, Högberg 1997, Hietz et al. 2002). However, differing from previous studies comparing foliar $\delta^{15} \mathrm{~N}$ values of host trees and their epiphytes (Stewart et al. 1995, Hietz et al. 2002), in the present study, only orchids had a more negative foliar $\delta^{15} \mathrm{~N}$ 
Table 4. Mean values ( $\pm \mathrm{SE}$ ) for foliar $\mathrm{N}$ and $\mathrm{C}$ concentration, $\mathrm{C}: \mathrm{N}$ ratio, and $\delta^{15} \mathrm{~N}$ and $\delta^{13} \mathrm{C}$ of the tree $A$. heterophylla $(n=25)$ and their epiphytes ( $n=13$ aroids, 7 bromeliads and 20 orchids) sampled in an area of white-sand vegetation in the Central Brazilian Amazon.

\begin{tabular}{llccc}
\hline Plant group & \multicolumn{1}{c}{$\% \mathrm{~N}$} & $\mathrm{CN}$ ratio & $\delta^{15} \mathrm{~N}$ & $\delta^{13} \mathrm{C}$ \\
\hline Aldina heterophylla & $2.1 \pm 0.06^{\mathrm{a}}$ & $23.6 \pm 0.8^{\mathrm{a}}$ & $-1.5 \pm 0.2^{\mathrm{a}}$ & $-29.4 \pm 0.1^{\mathrm{a}}$ \\
Aroids & $1.5 \pm 0.1^{\mathrm{b}}$ & $34.9 \pm 4.2^{\mathrm{ab}}$ & $-1.9 \pm 0.7^{\mathrm{a}}$ & $-30.9 \pm 1.0^{\mathrm{a}}$ \\
Bromeliads & $0.9 \pm 0.09^{\mathrm{b}}$ & $50.0 \pm 5.0^{\mathrm{b}}$ & $-1.3 \pm 0.6^{\mathrm{a}}$ & $-17.5 \pm 0.3^{\mathrm{b}}$ \\
Orchids & $0.1 \pm 0.03^{\mathrm{b}}$ & $58.5 \pm 2.6^{\mathrm{b}}$ & $-3.6 \pm 0.3^{\mathrm{b}}$ & $-20.4 \pm 1.2^{\mathrm{b}}$ \\
\hline
\end{tabular}

Different letters indicate significant statistical differences among plant group $(P<0.05)$.

compared to the host tree $A$. heterophylla. This lack of difference may be related to the $\mathrm{N}$ dynamics in whitesand vegetations. While most of the tropical forests are N-rich ecosystems (Cuevas \& Medina 1986, Matson \& Vitousek 1987, Martinelli et al. 1999, Nardoto et al. 2008), white-sand vegetations are known to be N-poor ecosystems (Mardegan et al. 2009). They are known to efficiently use the available $\mathrm{N}$ sources (Medina \& Cuevas 2000) and to have significantly depleted foliar $\delta^{15} \mathrm{~N}$ signatures when compared to dense terra-firme forests (Nardoto et al. 2008, Mardegan et al. 2009).

The differences in foliar $\delta^{15} \mathrm{~N}$ values observed among aroid, bromeliad, and orchid dwellers, as well as within their taxa might be influenced by available Nsources (Stewart et al. 1995). As some of these sources have a limited supply, it is possible that epiphytes from distinct groups may access $\mathrm{N}$ from a similar and/or more than a single source (Gebauer \& Meyer 2003). In addition, epiphyte foliar $\delta^{15} \mathrm{~N}$ may also be influenced by the microhabitat within the canopy (Hietz \& HietzSeifert 1995, Hietz et al. 1999).

Canopy soil is the source with higher $\mathrm{N}$ concentrations in epiphytic habitats (Inselsbacher et al. 2007) and is mainly composed of organic matter; inorganic compounds when present are derived from the decomposition of organic debris (Wania et al. 2002). Canopy organic matter mostly accumulates over thicker branches and a decreasing gradient of nutrient supply from thicker to thinner branches may be expected (Wania et al. 2002). Thus, it is expected that epiphytes rooted in soil canopy over thicker branches improve their $\mathrm{N}$ supply by accessing $\mathrm{N}$ sources from decomposing canopy litter (soil canopy) compared to those over thinner branches (Hietz et al. 2002).

Despite that the aroids had a higher $\mathrm{N}$ foliar concentration and lower $\mathrm{C}: \mathrm{N}$ ratios, their isotopic signature was similar to the bromeliads. Aroid and bromeliad dwellers have distinct life forms. While the former are rooted in canopy soil, bromeliads obtain nutrients from water and debris accumulated within their impounding shoots (Benzing \& Renfrow 1974, Endres \& Mercier 2001, Scarano et al. 2002, Lüttge 2008). The initial discrimination against ${ }^{15} \mathrm{~N}$-enriched $\mathrm{N}$ compounds during microbial decomposition of accumulated canopy litter could lead to ${ }^{15} \mathrm{~N}$-enrichment of $\mathrm{N}$ sources within the tank water (Hietz \& Wanek 2003). In contrast, N compounds derived from rainwater usually have negative foliar $\delta^{15} \mathrm{~N}$ values (Clark \& Nadkarni 1990, Fukuzaki \& Hayasaka 2009). Based on our results, we were unable to quantify the contribution of these sources to the bromeliad $\mathrm{N}$ nutrition. According to the literature, it is likely that bromeliads may rely on the mineralization of canopy litter within tank shoots as a major source of N (Clark \& Benzing 1990, Reinert et al. 1997, Benzing 2000, Inselsbacher et al. 2007).

On the other hand, orchids had the most depleted foliar $\delta^{15} \mathrm{~N}$ values. They grow over thinner and bare branches and lack access to high quantities of canopy soil, such as the aroids, and do not have a reservoir structure for storing water and nutrients, such as bromeliads. As a consequence, they only have access to nutrients in the water running over their surface (Hietz et al. 1999) and from atmospheric deposition, sources that are proportionally more ${ }^{15} \mathrm{~N}$-depleted $(<-$ 3\%o) (Benzing 2000, Fukuzaki \& Hayasaka 2009). Moreover, lowland rainforest-orchids are commonly associated with mycorrhiza (Lesica \& Antibus 1990). This association enables a more efficient water and nutrient assimilation (Wania et al. 2002, Geabuer \& Meyer 2003, Midgley et al. 2005), although symbionts deliver isotopically depleted $\mathrm{N}$ compounds (Högberg 1997). Thus, the isotopic signatures found in orchids (up to $2 \%$ more depleted) may reflect a high reliance on $\mathrm{N}$ sources derived from atmospheric deposition and symbiotic association.

Photosynthetic types among epiphytes using stable C isotopic composition - Except for the aroids and one 
orchid genus (Encyclia), the majority of epiphytes sampled exhibited a CAM-photosynthetic pathway. Water availability is one of the main environmental factors limiting epiphyte growth and maintenance (Lüttge 2008). As a consequence, a large number of vascular epiphytes use the water-conserving CAMpathway of photosynthesis, typically associated with plants that inhabit areas where water supply is limited or intermittent, such as observed in epiphyte tropical habitats (Medina 1996, Cushman 2001). The $\mathrm{CO}_{2}-$ concentrating strategy of the CAM photosynthetic pathway (Hietz et al. 1999) results in lower transpiration rates and higher water use efficiency (WUE) than $\mathrm{C}_{3}$ - and $\mathrm{C}_{4}$-plants under comparable conditions (Zotz \& Winter 1994, Cushman 2001), allowing these plants to be very plastic and successfully irradiate throughout diverse environments (Medina 1987).

CAM expression greatly varies within epiphyte groups (Pierce et al. 2002), and internal variations are related to variation of environmental conditions (i.e., air humidity, light exposure) (Hietz et al. 1999). An evidence of such plasticity is the intrinsic ability that some species, known as facultative CAM, present to vary their photosynthetic strategy between $\mathrm{C}_{3}$ - and CAM- pathway in response to the environment (Pierce et al. 2002, Lüttge 2008, Reinert \& Blankenship 2010). For example, when CAM-plants face a condition of higher water availability, they may maximize their productivity using the $\mathrm{C}_{3}$ pathway, which has a lower energetic demand than the CAM-pathway. When water availability progressively reduces, plants return to merge this strategy with the CAM-pathway, reducing water loss and maintaining their photosynthetic integrity (Winter et al. 1978, Maxwell et al. 1995, Zotz \& Ziegler 1997). Additionally, constitutive CAM-species may vary the relative contribution of phase IV of CAM-pathway (stomata open during the day and carbon fixation via Rubisco) in relation to phase I (nightime $\mathrm{CO}_{2}$ fixation) (Griffiths et al. 1986, Reinert et al. 1997). Such variation is also related to environmental conditions. However, the ability to merge different photosynthetic pathways, leads CAM-plants to have intermediate $\delta^{13} \mathrm{C}$ values. Differently from $\mathrm{C}_{3}$ and $\mathrm{C}_{4}$-plants, which have well-defined and fixed values (-24 to $-38 \%$, and -11 to $-15 \%$, respectively), CAMplants may have intermediate ones (Griffiths et al. 1986), accordingly to the level of reliance on the $\mathrm{C}_{3}$-pathway. As pointed by Winter and Holtum (2002), epiphytic species with typical $\delta^{13} \mathrm{C}$ values of $\mathrm{C}_{3}$-plants may obtain a great part from their carbon through CAM-pathway. Thus, additional leaf analysis, such as those related to gas-exchange patterns and titrable acidity, may be useful to quantify the magnitude of carbon gain through this pathway (Pierce et al. 2002).

A vertical gradient in foliar $\delta^{13} \mathrm{C}$ can be observed in forests (Wania et al. 2002), with plants from lower strata typically having more negative $\delta^{13} \mathrm{C}$ values than those from the upper canopy (Ometto et al. 2006). This differentiation is normally related to the reduction in light intensity and in vapor pressure deficits associated with more sheltered canopy layers (Holtum \& Winter 2005), as well as to the origin of the assimilated $\mathrm{CO}_{2}$ (Martinelli et al. 2009). Medina (1987) showed a variation of 2 to $5 \%$ between epiphytic bromeliads from shaded and sunny areas, observing that the plants exposed to sunlight had a more ${ }^{13} \mathrm{C}$-enriched signature, indicative of a higher water use efficiency. However, foliar $\delta^{13} \mathrm{C}$ values were either typical of the $\mathrm{C}_{3}$ - or the CAM-pathway, suggesting, independently on canopy position, low impact of WUE variation throughout the year on the $\delta^{13} \mathrm{C}$ signature of the dry mass.

The values of foliar $\delta^{15} \mathrm{~N}$ and $\delta^{13} \mathrm{C}$ observed herein indicate that epiphytes develop numerous strategies to cope with the limiting conditions of their environment. Epiphyte foliar $\delta^{15} \mathrm{~N}$ values showed variation within families in relation to $\mathrm{N}$ resource used by these plants, being that source is related to habitat quality and epiphyte life form. Orchid foliar $\delta^{15} \mathrm{~N}$ indicates the use of depleted $\mathrm{N}$ sources from precipitation, as well as the use of sources derived from symbiotic associations. The foliar $\delta^{15} \mathrm{~N}$ values of aroid and bromeliad dwellers indicate that, despite having distinct life forms, these groups may access similar $\mathrm{N}$ sources. The $\mathrm{N}$ derived from the decomposition of organic matter in canopy soil, as well as within tanks seems to be the major source for these two epiphytic groups. Regarding the photosynthetic pathway, foliar $\delta^{13} \mathrm{C}$ showed that both $\mathrm{CAM}$ and $\mathrm{C}_{3^{-}}$ pathways are present among these epiphytes.

Acknoledgements - We wish to thank the Instituto Nacional de Pesquisas da Amazônia for logistical support; M.Z. Moreira, M.A. Perez and F. Fracassi (Centro de Energia Nuclear na Agricultura / USP) for laboratory assistance; and the field auxiliaries for their contributions. Sílvia Mardegan had a fellowship from the "Programa de Pós-Graduação em Ecologia do Instituto Nacional de Pesquisas da Amazônia", and this research was supported by grants from $\mathrm{CNPq}$ (Project PPI 2-3105).

\section{References}

ANDERSON, A.B. 1981. White-sand vegetation of Brazilian Amazonia. Biotropica 13:199-210. 
BENAVIDES, D.A.M., DUQUE, M., ÁlVARO, J., DUIVENVOORDEN, J.F., VASCO, G.A. \& DALLEJAS, R. 2005. A first quantitative census of vascular epiphytes in rain forests of Colombian Amazonia. Biodiversity and Conservation 14: 739-758.

BENZING, D.H. 1990. Vascular epiphytes. Cambridge University Press, Cambridge.

BENZING, D.H. 2000. Bromeliaceae: profile of an adaptive radiation. Cambridge University Press, Cambridge.

BENZING, D.H. \& RENFROW, A. 1974. The mineral nutrition of the Bromeliaceae. Botanical Gazette 135:281-288.

BRAGA, P.I.S. 1979. Subdivisão fitogeográfica, tipos de vegetação, conservação e inventário florístico da Floresta Amazônica. Acta Amazonica 9:53-80.

CLARK, K. \& NADKARNI, N. 1990. Nitrate and ammonium ions in precipitation and throughfall of a neotropical cloud Forest: implications for epiphyte mineral nutrition. Ecological Bulletins 71:59.

CUSHMAN, J.C. 2001. Crassulacean acid metabolism: a plastic photosynthetic adaptation to arid environments. Plant Physiology 127:1439-1448.

CUEVAS, E. \& MEDINA, E. 1986. Nutrient dynamics within Amazonian Forests. I. Nutrient flux in fine litter fall and efficiency of nutrient utilization. Oecologia 68:466472.

DAWSON, T.E., MAMBELLI, S., PLAMBOECK, A.H., TEMPLER, P.H. \& TU, K.P. 2002. Stable isotopes in plant ecology. Annual Review of Ecology Systematics 33:507-559.

EDWARDS, P.J. \& GRUBB, P.J. 1977. Studies of mineral cycling in a montane rainforest in New Guinea 1 . The distribution of organic matter in the vegetation and soil. Journal of Ecology 65:943-69.

ENDRES, L. \& MERCIER, H. 2001. Ammonium and urea as $\mathrm{N}$ sources for bromeliads. Journal of Plant Physiology 158:205-212.

FONTOURA, T. \& REINERT, F. 2009. Habitat utilization and CAM occurrence among epiphytic bromeliads in a dry forest from southeastern Brazil. Revista Brasileira de Botânica 32:521-530.

FUKUZAKI，N. \& HAYASAKA，H. 2009. Seasonal variations of nitrogen isotopic ratios of ammonium and nitrate in precipitations collected in the Yahiko-Kakuda Mountains area in Niigata Prefecture, Japan. Water Air Soil Pollution 203:391-397.

GEBAUER, G. \& MEYER, M. 2003. ${ }^{15} \mathrm{~N}$ and ${ }^{13} \mathrm{C}$ natural abundance of autotrophic and mycoheterotrophic orchids provides insight into nitrogen and carbon gain from fungal association. New Phytologist 160: 209-223.

GENTRY, A.H. \& DODSON, C.H. 1987. Contribution of nontrees to species richness of a tropical rain forest. Biotropica 19:149-156.
GRIFFITHS, H., LIITTGE, L.E., STIMMEL, K.H., CROOK, C.E., GRIFFITHS, N.M. \& SMITH, J.A.C. 1986. Comparative ecophysiology of CAM and $\mathrm{C} 3$ bromeliads. III. Environmental influences on $\mathrm{CO}_{2}$ assimilation and transpiration. Plant, Cell and Environment 9:385-393.

GUILLAMET, J.-L. 1987. Some structural and floristic aspects of the forest. Experientia 43:241-251.

HIETZ, P. \& HIETZ-SEIFERT, U. 1995. Composition and ecology of vascular epiphyte communities along an altitudinal gradient in central Veracruz, Mexico. Journal of Vegetation Science 6:487-498.

HIETZ, P. \& WANEK, W. 2003. Size dependent variation of carbon and nitrogen isotope abundances in epiphytic bromeliads. Plant Biology 5:137-142.

HIETZ, P., WANEK, W. \& POPP, M. 1999. Stable isotopic composition of carbon and nitrogen and nitrogen content in vascular epiphytes along an altitudinal transect. Plant, Cell and Environment 22:1435-1443.

HIETZ, P., WANEK, W., WANIA, R. \& NADKARNI, N.M. 2002. Nitrogen-15 natural abundance in a montane cloud forest canopy as an indicator of nitrogen cycling and epiphyte nutrition. Oecologia 131:350-355.

HÖGBERG, P. 1997. ${ }^{15} \mathrm{~N}$ natural abundance in soil-plant systems. New Phytologist 137:179-203.

HOLTUM, J.A.M. \& WINTER, K. 2005. Carbon isotope composition of canopy leaves in a tropical forest in Panama throughout a seasonal cycle. Trees 19:545551.

HORBE, A.M.C., HORBE, M.A. \& SUGUIO, K. 2004. Tropical spodosols in Northeastern Amazonas State, Brazil. Geoderma 119:55-68.

INGRAM, S.W. \& NADKARNI, N.M. 1993. Composition and distribution of epiphytic organic matter in a Neotropical cloud forest, Costa Rica. Biotropica 25:370-383.

INSELSBACHER, E., CAMBUI, C.A., RICHTER, A., STANGE, C.F., MERCIER, H. \& WANEK, W. 2007. Microbial activities and foliar uptake of nitrogen in the epiphytic bromeliad Vriesea gigantea. New Phytologist 175:311-320.

KAUFF, F., RUDALL, P.J. \& CONRAN, J.G. 2000. Systematic root anatomy of Asparagales and other monocotyledons. Plant Systematics and Evolution 223:139-154.

LESICA, P. \& ANTIBUS, R.K. 1990. The occurrence of mycorrhizae in vascular epiphytes of two Costa Rican rain forests. Biotropica 22:250-258.

LÜTTGE, U. 2008. Physiological ecology of tropical plants $\left(2^{\text {nd }} e d.\right)$. Springer-Verlag, Berlin.

LUIZÃO, F.J., LUIZÃO, R.C.C. \& PROCTOR, J. 2007a. Soil acidity and nutrient deficiency in central Amazonian heath forest soils. Plant Ecology 192:209-224.

LUIZÃO, R.C.C., LUIZÃO, F.J. \& PROCTOR, J. 2007 b. Fine root growth and nutrient release in decomposing leaf litter in three contrasting vegetation types in central Amazônia. Plant Ecology 192:225-236. 
MARDEGAN, S.F., NARDOTO, G.B., HIGUCHI, N., MOREIRA, M.Z. \& MARTINELLI, L.A. 2009. Nitrogen availability patterns in white-sand vegetations of Central Brazilian Amazon. Trees 23:479-488.

MARTINELLI, L. A., OMETTO, J.P.H.B., FERRAZ, E.S., VICOTRIA, R.L., CAMARGO, P.B. \& MOREIRA, M.Z. 2009. Desvendando questões ambientais com isótopos estáveis. Oficina de Textos, São Paulo.

MARTINELLI, L.A., PICCOLLO, M.C., TOWNSEND, A.R., VITOUSEK, P.M., CUEVAS, E., MCDOWELL, W., ROBERTSON, G.P., SANTOS, O.C. \& TRESENDER, K. 1999. Nitrogen stable isotopic composition of leaves and soil: tropical versus temperate forests. Biogeochemistry 46:45-65.

MEDINA, E., DELGADO, M., THROUGHTON, J.H. \& MEDINA, J.D. 1977. Physiological ecology of $\mathrm{CO}_{2}$ fixation in Bromeliaceae. Flora 166:137-152.

MEDINA, E. 1987. Aspectos ecofisiológicos de plantas CAM en los trópicos. Revista de Biología Tropical 35:55-70.

MEDINA, E. 1996. CAM and C4 plants in the humid tropics. In Tropical forest plant eco-physiology (S.S. Mulkey, R.L. Chazdon \& A.P. Smith, eds.). Chapman \& Hall, New York.

MEDINA, E., OLIVARES, E., DÍAZ, M. \& VAN DER MERWE, N. 1989. Metabolismo ácido de crassuláceas em bosques húmedos tropicales. Monographs in Systematics Botany from the Missouri Botanical Garden 27:56-67.

MEDINA, E. \& CUEVAS, E. 2000. Eficiéncia de utilización de nutrientes por las plantas leñosas: eco-fisiología de bosques de San Carlos de Río Negro. Scientia Guaianae 11:51-70.

MEDinA, E., DELGAdo, M., TROUGHTON, J.H. \& MEDINA, J.D. 1977. Physiological ecology of $\mathrm{CO}_{2}$ fixation in Bromeliaceae. Flora 166:137-152.

MIDGLEY, D.J., JORDAN, L.A., SALEEBA, J.A. \& MCGEE, P.A. 2005. Utilization of carbon substrates by orchid and ericoid mycorrhizal fungi from Australian dry sclerophyll forests. Mycorrhiza 16:175-182.

NADKARNI, N.M. 1984. Epiphyte biomass and nutrient capital of a Neotropical elfin forest. Biotropica 16:249256.

NADKARNI, N.M. 1986. The nutritional effects of epiphytes on host trees with special reference to alteration of precipitation chemistry. Selbyana 9:44-51.

NADKARNI, N.M. \& MATELSON, T.J. 1992. Biomass and nutrient dynamics of epiphytic litterfall in a Neotropical montane forest, Costa Rica. Biotropica 24:24-30.

NADKARNI, N.M., LAWTON, R.O., CLARK, K.L., MATELSON, T.J. \& SCHAEFER, D. 2000. Ecosystem ecology and forest dynamics. In Monteverde - Ecology and conservation of a tropical cloud forest (N. Nadkarni \& N.T. Wheelwright, eds.). Oxford University Press, New York.
NARDOTO, G.B., OMETTO, J.P.H.B., EHLERINGER, J.R., HIGUCHI, N., BUSTAMANTE, M.M.C. \& MARTINELLI, L.A. 2008. Understanding the influences of spatial patterns on the $\mathrm{N}$ availability within the Brazilian Amazon Forest. Ecosystems 11:1234-1246.

OMETTO, J.P.H.B., EHLERINGER, J.R., DOMINGUES, T.F., BERRY, J.A., ISHIDA, F.Y., MAZZI, E., HIGUCHI, N., FLANAGAN, L.B., NARDOTO, G.B. \& MARTINELLI, L.A. 2006. The stable carbon and nitrogen isotopic composition of vegetation in tropical forests of the Amazon region, Brazil. Biogeochemistry 79:251-274.

PIERCE, S., WINTER, K. \& GRIFFITHS, H. 2002. Carbon isotope ratio and the extent of daily CAM use by Bromeliaceae. New Phytologist 156:75-83.

PIRES, J.M. \& PRANCE, G.T. 1985. The vegetation types of Brazilian Amazon. In Amazonia (G.T. Prance \& T.E. Lovejoy, eds.). Pergamon Press, Oxford.

PROCTOR, J. 1999. Heath forests and acid soils. Botanical Journal of Scotland 51:1-14.

RAINS, K.C., NADKARNI, N.M. \& BLEDSOE, C.S. 2003. Epiphytic and terrestrial mycorrhizas in a lower montane Costa Rican cloud Forest. Mycorrhiza 13:257-264.

REINERT, F. \& BLANKENSHIP, R.E. 2010. Evolutionary aspects of crassulacean acid metabolism. Oecologia Australis 14:359-368.

REINERT, F, GRIFFITHS, H., WILSON, J., RIBAS, L., CARDINOT, G. \& ROBERTS, A. 1997. Gradation in nutrient composition and photosynthetic pathway in relation to zonation of restinga vegetation of Brazil. Botanica Acta 110:135-142.

RICHARDS, P.W. 1996. The tropical rain forest - an ecological study. $2^{\text {nd }}$ ed., Cambridge University Press, Cambridge.

SCARANO, F.R., DUARTE, H.M., RÔÇAS, G., BARRETO, S.M.B., AMADO, F.M., REINERT, F., WENDT, T., MANTOVANI, A., LIMA, H.R.P. \& BARROS, C.F. 2002. Acclimation or stress symptom? An integrated study of intraspecific variation in the clonal plant Aechmea bromeliifolia, a widespread CAM tankbromeliad. Botanical Journal of the Linnean Society 140:391-401.

SHEFFERSON, R.P., WEISS, M., KULL, T. \& TAYLOR, D.L. 2005. High specificity generally characterizes mycorrhizal association in rare lady's slipper orchids, genus Cypripedium. Molecular Ecology 14:613-626.

SOMBROEK, W. 2001. Spatial and temporal patterns of Amazon rainfall: consequences for the planning of agricultural occupation and the protection of primary forests. Ambio 30:388-396.

STATSOFT, INC. 2004. Statistica 6.0. www.statsoft.com.

STEWART, G.R., AIDAR, M.P.M., JOLY, C.A. \& SCHMIDT, S. 2002. Impact of point source pollution on nitrogen isotope signatures $\left(\delta^{15} \mathrm{~N}\right)$ of vegetation in SE Brazil. Oecologia 131:468-472. 
STEWART, R.R., SCHIMIDT, S., HANDLEY, L.L., TURNBULL, M.H., ERSKINE, P.D. \& JOLY, C.A. 1995. ${ }^{15} \mathrm{~N}$ natural abundance of vascular rainforest epiphytes: implications for nitrogen source and acquisition. Plant, Cell and Environment 18:85-90.

TAKEUCHI, M. 1960. A estrutura da vegetação na Amazônia. III - A mata de campina na região do Rio Negro. Boletim do Museu Paraense Emílio Goeldi - Botânica 8: $1-13$.

TSAVKELOVA,E.A.,LOBAKOVA,E.S.,KOLOMEITSEVA, G.L., CHERDYNTSEVA, T.A. \& NETRUSOV, A.I. 2003. Localization of associative Cyanobacteria on the roots of epiphytic orchids. Microbiology 72: 86-91.

WANIA, R., HIETZ, P. \& WANEK, W. 2002. Natural ${ }^{15} \mathrm{~N}$ abundance of epiphytes depends on the position within the forest canopy:source signals and isotope fractionation. Plant, Cell and Environment 25:581-589.
WINTER, K. \& HOLTUM, J.A.M. 2002. How closely do the $\delta^{13} \mathrm{C}$ values of CAM plants reflect the proportion of $\mathrm{CO}_{2}$ fixed during day and night? Plant Physiology 129:1843-1851.

WINTER, K., LÜTTGE, U., WINTER, E. \& TROUGHTON, J.H. 1978. Seasonal shift from $\mathrm{C}_{3}$ photosynthesis to crassulacean acid metabolism in Mesembryanthemum crystallinum growing in its natural environment. Oecologia 34:225-237.

YODA, K. 1974. Three-dimensional distribution of light intensity in a tropical rain forest of West Malaysia. Japanese Journal of Ecology 24:247-254.

ZOTZ, G.Z. \& WINTER, K. 1994. Annual carbon balance and nitrogen use efficiency in tropical $\mathrm{C}_{3}$ and CAM epiphytes. New Phytologist 126:481-492.

ZOTZ, G. \& ZIEGLER, H. 1997. The occurrence of crassulacean acid metabolism among vascular epiphytes from Central Panama. New Phytologist 137:223-229. 